\title{
PSO BASED OPTIMAL DISTRIBUTED GENERATION PLACEMENT AND CAPACITY BY CONSIDERING HARMONIC LIMITS
}

\author{
R. M. Sasiraja, K. Muthulakshmi, V. Suresh Kumar, T. Abinaya
}

Original scientific paper

Distributed Generation (DG) units are also called Dispersed Generation, Decentralized Generation and Embedded Generation. They are normally smal generating plants, connected directly to either distribution side or customer side. The installation of inverter-based distributed generation (DG) has increased rapidly in recent years. This higher penetration level may result in the increased level of harmonics, which could exceed the permissible harmonic distortion level. The penetration level of DG is restricted by harmonic distortion, because of the nonlinear current injected by inverter based DG units. In this work, the maximum DG penetration level is determined, by considering the harmonic limits. The harmonics are determined by using the Decoupled Harmonic Power Flow (DHPF) approach. The constraints of this proposed problem include power balance equations, bus voltage limits, total and individual harmonic distortion limits specified by IEEE-519 standard. The problem is solved by using Particle Swarm Optimization (PSO) algorithm based optimization technique. Simulation results are obtained by MATPOWER/MATLAB in IEEE 30 and IEEE 57 bus test systems and the results prove the effectiveness of this proposed approach.

Keywords: Decoupled Harmonic Power Flow (DHPF); Distributed Generation (DG); harmonic distortion; Particle Swarm Optimization (PSO)

\section{Na optimizaciji roja čestica utemeljeno optimalno razmještanje i kapacitet decentralizirane proizvodnje uzimajući u obzir harmonijska ograničenja}

Izvorni znanstveni članak

Jedinice decentralizirane proizvodnje (DG units) također se nazivaju raspršenom proizvodnjom, decentraliziranom proizvodnjom i ugrađenom proizvodnjom. Uobičajeno su to male elektrane, direktno povezane bilo s distribucijom ili potrošačem. Uspostava decentralizirane proizvodnje na temelju invertera rapidno se povećala zadnjih godina. To može biti rezultat povećane razine sekundarne frekvencije koja može prekoračiti dopušenu razinu harmonijskog izobličenja. Razina prodiranja DG ograničena je harmonijskim izobličenjem zbog nelinearne struje iz DG jedinica na bazi invertera. U ovom je radu određena maksimalna razina penetracije DG, uzimajući u obzir harmonijska ograničenja. Harmonici su određeni pristupom odvojenog harmonijskog protoka snage (DHPF). Ograničenja ovog predloženog problema uključuju jednadžbe balansiranja snage, ograničenja napona sabirnice, ukupne i pojedinačne granice harmonijskog izobličenja specificiranog normom IEEE-519. Problem je riješen primjenom tehnike optimizacije pomoću algoritma optimizacije roja čestica. Rezultati simulacije dobiveni su primjenom MATPOWER/MATLAB u sustavima ispitivanja sabirnice IEEE 30 i IEEE 57, a rezultati dokazuju učinkovitost predloženog pristupa.

Ključne riječi: decentralizirana proizvodnja; harmonijsko izobličenje; odvojeni harmonijski protok snage; optimizacija roja čestica

\section{Introduction}

Distributed Generation units are generally small-scale (typically $1 \mathrm{~kW} \div 50 \mathrm{MW}$ ) electric power generators that can produce electricity at a site, close to customers or that are tied to an electric distribution system. The penetration of renewable based DG resources has created an important role in the future electricity scenario. This is because of its improved performance, reliability, flexibility in achieving increased energy efficiency and reduced emission [1-2]. Hence, an optimal DG placement is the most significant thing to improve the network performance in terms of improved voltage profile, reduced system losses and improved power quality.

The distributed resources are interconnected with electric power systems according to IEEE-1547 standard [3]. There are two types of DG units, namely utility owned and customer owned DG units [4]. In the case of a utility owned DG installation, the utility has to optimally plan the location and size of the DG units in order to improve network benefits and reliability [5]. The identification of the best locations for renewable based DGs and the impact of critical uncertainties are presented in a local distribution system [6]. However, it is difficult to find cost-effectiveness of renewable based DGs. An Ordinal Optimization (OO) approach is presented for solving the DG planning problem with discrete and continuous variables [7].
An Artificial Bee Colony ( $\mathrm{ABC}$ ) algorithm is used to determine the size and location of optimal DG units in order to minimize the total system real power loss, improve the network benefits and reliability. Due to the requirement of more data that algorithm is difficult to implement [8]. Planning for DG is discussed, which includes capital cost, operating cost, planning of emergency limits and normal limits [9]. A new optimization problem is proposed to determine the maximum DG penetration level, by optimally selecting types, locations and sizes of utility owned DG units [10]. That approach has proved that the DG interconnection in distribution system produces significant impacts both for the customers and the electric utilities.

Due to the development of fast semiconductor switches and also the introduction of real-time controllers, power-electronic technology plays a very important role in minimizing harmonic distortion in order to achieve higher efficiency and reliability [11]. The inverter-based DG units comparetively have more impact on system harmonic levels than synchronous-based DG units. The current and voltage harmonics affect the performance of various power electronics devices. The modeling of harmonic analysis is given by the IEEE-519 standard [12].

The penetration level of photovoltaic generation in a radial distribution system is investigated, including the limits of voltage magnitude and conductor current flow [13]. An analytical approach is discussed to minimize the 
system losses, by installing various types of DG units like $\mathrm{PV}$, wind, fuel cell and micro turbine which injects both real and reactive power [14]. The various methods of harmonic load flow formulations are discussed and the increase of nonlinear devices in electric power system is addressed [15].

The design of harmonic passive filter is presented and it is reported for the use of harmonic disturbance reduction. However, the linear and nonlinear loads in the radial distribution systems have a number of characteristics, which make the harmonic filter planning very difficult [16]. Among the various harmonic mitigation methods, the most commonly employed method is tuned passive filters due to its cost and simplicity. The multi objective nonlinear programming (MONLP) problem with fuzzy parameters is implemented for passive filter design using genetic algorithm [17].

The optimal selection and placement of capacitor bank is essential, because the inappropriate placement of capacitors could cause harmonics. Fuzzy based approach is used for optimal placement and sizing of capacitor banks in the presence of voltage and current harmonics [18]. A new method is presented for limiting harmonic voltage distortion with harmonic passive filter, by considering the probabilistic characteristics of harmonic currents and harmonic impedances [19]. The placement of multi-location distributed generation is presented to minimize the total active power loss and to improve the system performance using genetic algorithm [20].

\section{Proposed Work}

The harmonics injected by the power electronics and electromagnetic devices have increased drastically and they become more and more dangerous. This proposed work identifies the maximum penetration level of multiple distributed generations, by considering harmonic limits within the stipulated levels. The individual and total harmonic distortion levels are calculated, by the decoupled harmonic power flow analysis and these factors are kept as constraints in the PSO based optimization problem. The objective of this optimization problem is the maximization of penetration level of DGs. PSO is used in this proposed optimization problem and this approach is tested in IEEE 30 and IEEE 57 bus test systems.

The remaining chapters of this manuscript are structured as follows. Chapter 3 addresses the problem formulation of this proposed approach along with the calculation of harmonic power flow analysis. In chapter 4 , the details of objective function and constraints are presented. Chapter 5 discusses the brief introduction of PSO and the algorithm steps involved in this work. Chapters 6 and 7 discuss the results of this proposed work and statistical investigation, respectively. Some of the important conclusions are presented in Chapter 8.

\section{Problem Formulation}

The objective of this problem is to maximize the DG penetration level, by selecting the optimal size of inverter based DG units, using Particle Swarm Optimization (PSO) algorithm. The constraints of the problem include bus voltage limits, individual harmonic limits, total harmonic limits and power balance constraints. The formulation and the details of this proposed problem are described in the following subsections.

\subsection{Harmonic Power Flow Analysis}

Inverter based DG units like solar photovoltaics and fuel cells might cause harmonics. The injection of harmonic currents can distort the original voltage waveform and can limit the amount of DG penetration. This small voltage distortion can cause large harmonic currents especially for inverter based DG units and can lead to high-voltage distortion. Among the various harmonic power flow formulations, the Decoupled Harmonic Power Flow (DHPF) is the most commonly used method to estimate the harmonic distortion due to its simplicity [16]. The flowchart of DHPF analysis is shown in Fig. 1.

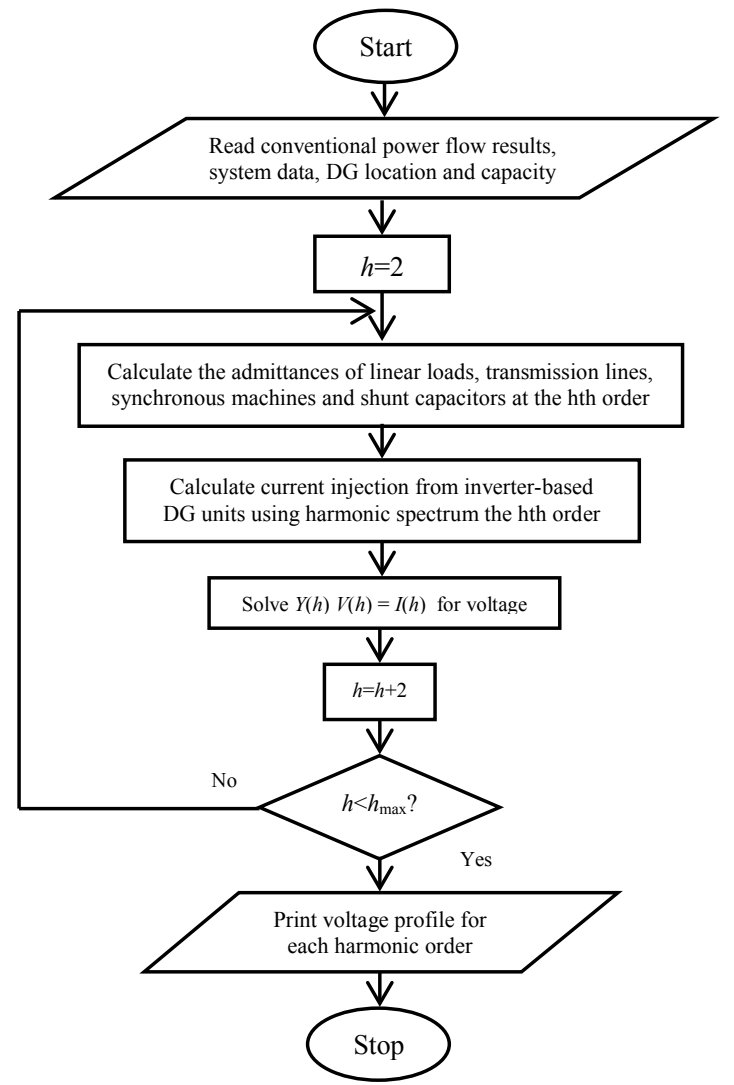

Figure 1 Flowchart of Decoupled Harmonic Power Flow analysis

Initially, the results of conventional power flow, system data, DG location and capacity are given as input to DHPF analysis. In higher order harmonic frequencies the shunt capacitors, transmission lines and linear loads are modelled as equivalent admittances using the results of the conventional power flow and then, a new admittance matrix is formulated. Inverter-based DG units are modelled as harmonic current injecting sources in the DHPF method. For each individual harmonic order $h$, the nodal equations are formulated to obtain the harmonic voltage and the corresponding result is applied to estimate the harmonic distortion [16].The various elements of harmonic admittances are shown as follows:

$y_{i}^{(h)}=\frac{P_{D, i}}{\left|v_{i}^{(1)}\right|^{2}}-j \frac{Q_{D, i}}{h\left|v_{i}^{(1)}\right|^{2}}$, 
$y_{c i}^{(h)}=h y_{c i}^{(1)}$,

$y_{i, i+1}^{(h)}=\frac{1}{R_{i, i+1}+j h X_{i, i+1}}$.

The harmonic admittance matrix $\boldsymbol{Y}(h)$ is developed by using harmonic admittances of various factors. The $h^{\text {th }}$ harmonic order current $\left(I_{i}(h)\right)$ is given by

$$
\begin{aligned}
I_{i}^{(1)} & =\left[\frac{P_{D G, i}^{\mathrm{inv}}+j P_{D G, i}^{\mathrm{inv}}}{\left|v_{i}^{(1)}\right|}\right]^{*}, \\
I_{i}^{(1)} & =C(h) I_{i}^{(1)} .
\end{aligned}
$$

The harmonic voltage profile is expressed as follows:

$$
\boldsymbol{Y}(h) V(h)=I(h) \text {. }
$$

\section{Objective Function}

The penetration level of DG is limited by the harmonic distortion, which is due to the nonlinear current injected, by inverter-based DG units. The primary aim is to maximize the DG penetration level with regard to full system capability. The objective function $F$ can be defined as follows:

Maximize $F=\frac{\sum_{i=1}^{N_{\text {bus }}} P_{D G, i}^{\text {inv }}}{\text { Total } M V A} \times 100 \%$.

\subsection{System Constraints}

The possibility of getting accurate results from any optimization problem primarily depends upon the consideration of all influencing parameters as constraints. The constraints available in this problem are identified and listed as follows.

\subsection{Equality Constraints}

The power balance constraints at the fundamental frequency for each bus i can be given as follows:

$$
\begin{aligned}
& P_{G, i}+P_{D G, i}^{\text {inv }}-P_{D, i}= \\
& =\sum_{j=1}^{N_{\text {bus }}}\left|v_{i}^{(1)} \| v_{j}^{(1)}\right|\left|v_{i, j}^{(1)}\right| \cos \left(\theta_{i, j}^{(1)}-\delta_{i}^{(1)}+\delta_{j}^{(1)}\right), \\
& Q_{G, i}+Q_{D G, i}^{\text {inv }}-Q_{D, i}= \\
& =\sum_{j=1}^{N_{\text {bus }}}\left|v_{i}^{(1)} \| v_{j}^{(1)}\right|\left|v_{i, j}^{(1)}\right| \sin \left(\theta_{i, j}^{(1)}-\delta_{i}^{(1)}+\delta_{j}^{(1)}\right) .
\end{aligned}
$$

\subsection{Inequality Constraints}

The bus voltage limits, total and individual harmonic distortion limits are considered as inequality constraints.

\subsubsection{Bus Voltage Limits}

The rms voltage magnitude of $i^{\text {th }}$ bus is given as follows:

$v_{i}^{\min } \leq \sqrt{\left|v_{i}^{(1)}\right|^{2}+\sum_{\mathrm{h}=2}^{h_{\max }}\left|v_{i}^{(h)}\right|^{2}} \leq v_{i}^{\max }$,

where $v_{i}^{\min }$ and $v_{i}^{\max }$ are the lower and upper rms voltage limits, which are set at 0.95 p.u. and 1.05 p.u., respectively.

\subsubsection{Total Harmonic Distortion Limits}

The total voltage harmonic distortion at each bus $i$ is as follows:

$$
T H D_{v, i}(\%)=\frac{\sqrt{\sum_{h=2}^{h_{\max }}\left|v_{i}^{(h)}\right|^{2}}}{\left|v_{i}^{(1)}\right|} \times 100 \leq T H D_{v}^{\max }
$$

where, is $T H D_{v}^{\max }$ the maximum permissible total voltage harmonic distortion limit, which is usually set at $5 \%$.

\subsubsection{Individual Harmonic Distortion Limits}

The individual voltage harmonic distortion at each bus $i$ is as follows:

$$
I H D_{v, i}^{(h)}(\%)=\frac{\left|v_{i}^{(h)}\right|}{\left|v_{i}^{(1)}\right|} \times 100 \leq I H D_{v}^{\max , h}
$$

where, $I H D_{v}^{\max , h}$ is the maximum allowable voltage harmonic distortion level at harmonic order and is considered as $3 \%$.

\subsection{Constraints Handling}

The voltage constraint ( $\left.V_{\text {constraint}}\right)$ is initialized as 0 then, the bus voltage limit constraint in Eq. (10) can be rewritten as follows,

Checking voltage limits

if, $V>V_{\min }$ and $V<V_{\max }$

then, $V_{\text {constraint }}=0$

ekse, $V_{\text {constraint }}=50$

Finally, subtract the $V_{\text {constraint }}$ with an objective function,

fit $=$ penetration $-V_{\text {constraint }}$

The proposed problem is the maximization problem and hence, the violated results are left out. The same approach is also used for all the remaining constraints. 


\section{Particle Swarm Optimization (PSO)}

Particle Swarm Optimization (PSO) is a heuristic global optimization technique developed by Kennedy and Eberhart in 1995. It is inspired by social behaviour of bird flocking or fish schooling. The PSO process starts with the generation of random population. It proceeds with the update of velocity and new position of the particle. At each iteration, the best solution is recorded and it is predicted as local best solution. All best solutions in the record are compared with each other and the best one is called as global best solution.

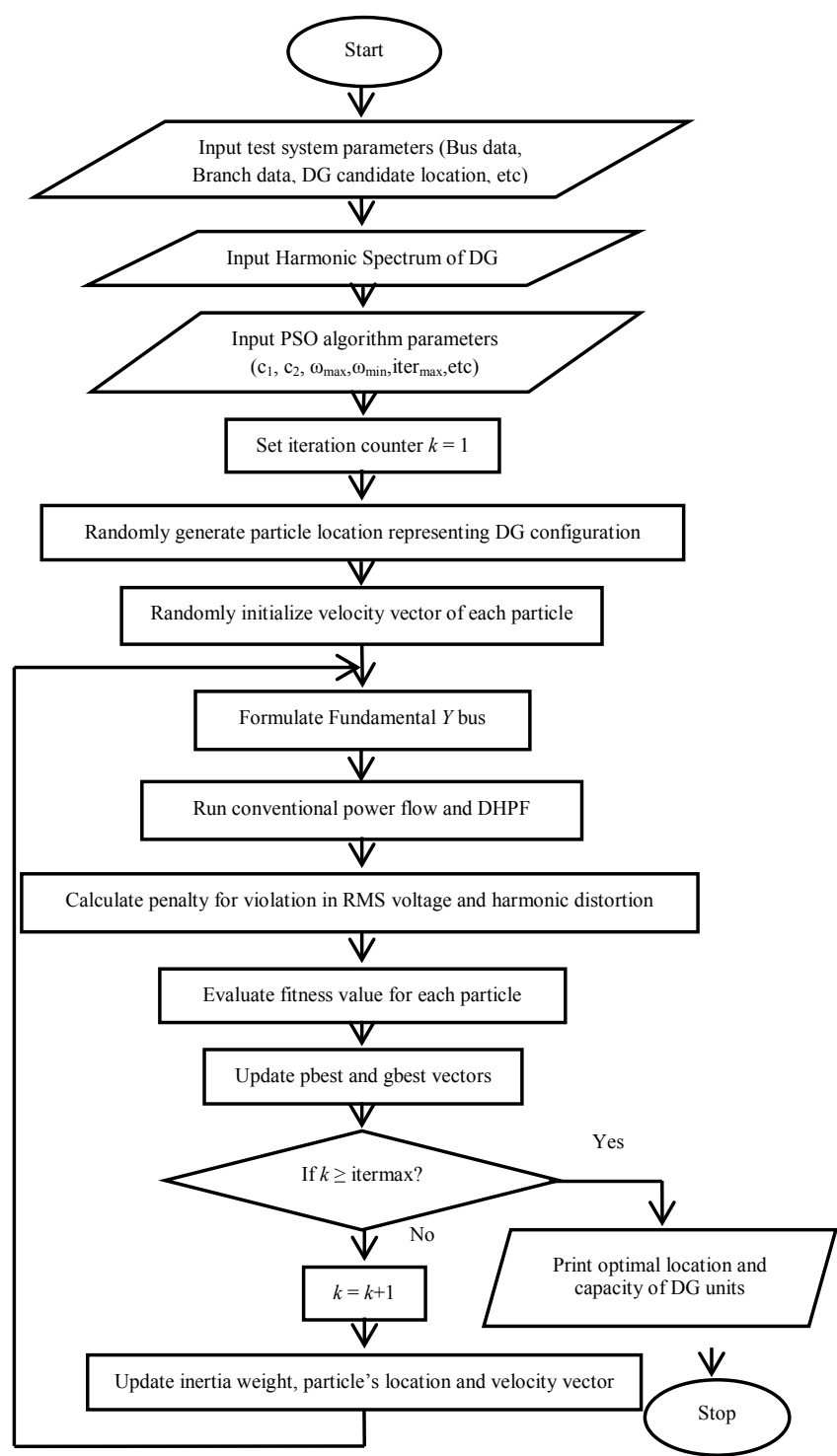

Figure 2 Flowchart of PSO-based optimal DG penetration

These values have an influence on the velocity and the movement of particles in the following iteration. Each particle maintains its individual best position (pbest), and swarm maintains its global best (gbest). The velocity and particle position are updated by the following equations.

$$
\begin{aligned}
& v_{i, d}^{k+1}= \\
& =\omega v_{i, d}^{k}+c_{1} r_{1}\left(\text { pbest }_{i, d}^{k}-x_{i, d}^{k}\right)+c_{2} r_{2}\left(\text { gbest }_{i, d}^{k}-x_{i, d}^{k}\right), \\
& x_{i, d}^{k+1}=x_{i, d}^{k}+v_{i, d}^{k+1} .
\end{aligned}
$$

In order to obtain a better balance between global exploration and local exploitation, the inertia weight is decreased linearly with the number of iterations [21]. The inertia weight is updated at each iteration as follows:

$\omega=\omega_{\max }-\frac{\omega_{\max }-\omega_{\min }}{\text { Iter }_{\max }} \times k$

The application of PSO algorithm for finding the optimal DG penetration level, by considering the harmonics and its computational steps are shown in a flow chart in Fig. 2 and also are listed as follows.

1. The bus and branch data of test system and DG locations are given as input.

2. Population of individuals and the velocity vectors are randomly initialized.

3. Conventional NR power flow is run for each individual and it can be solved by using real and reactive power balance at fundamental frequency.

4. The harmonic admittance matrix is calculated for each harmonic order $h$.

5. Then, DHPF algorithm is run for estimating the harmonic voltage components using Eq. (6).

6. The objective function of each individual particle is evaluated and the penalty function is added, if there is any constraint violation and then, pbest and gbest vectors are found.

7. The results are printed, if termination criterion is satisfied otherwise, go to step 8 .

8. The velocity and location of the particle is updated and then the process is again repeated from step 2 .

9. Optimal location and capacity of DG units are taken as output.

The parameters that are considered in this proposed algorithm are presented in Tab. 1 .

Table 1 Parameters of proposed algorithm

\begin{tabular}{|l|c|}
\hline \multicolumn{1}{|c|}{ Parameters } & Values \\
\hline$C_{1}$ & 2 \\
\hline$C_{2}$ & 2 \\
\hline Population size & 20 \\
\hline Maximum iteration & 100 \\
\hline No. of DG units & 12 \\
\hline
\end{tabular}

\section{$6 \quad$ Results and Discussion}

The proposed problem of maximizing the DG penetration level is implemented in MATPOWER and tested in IEEE 30 and IEEE 57 bus system. Two case studies are directed to demonstrate the effectiveness of this optimization problem. In this work, the population size is set to 20 and the maximum number of iterations is set to 100 .

Case I -For IEEE 30 bus system Case II -For IEEE 57 bus system

The necessary and required codes are developed, by writing an M-file in Matlab/Matpower version 4.1. Matpower is a package of Matlab M-files and it is effectively used for solving power flow and optimal power flow. Matpower is potentially designed to yield the 
best performance, while maintaining the codes simple to infer and to change.

\subsection{Case I - IEEE 30 bus system}

In this case, the results are tested in IEEE 30 bus system. The single line diagram of IEEE 30 bus system is depicted in Fig. 3. This network has six generators, 21 loads and 41 branches.

For IEEE 30 bus system, the following assumptions are observed in this methodology in order to certify the accurateness of this projected approach.

- The boundaries of bus voltages are set at 0.95 and 1.05 p.u., respectively.

- The maximum numbers of DG units are taken as 12 .

- The minimum and maximum values of DGare limited between $0.1 \div 5 \mathrm{MW}$, respectively.

Initially, the base case load flow is performed and the corresponding values of power flows, bus voltages and line losses are observed. Then, the THD values are calculated for all the load buses, using DHPF analysis. Then, the estimated values are arranged in an ascending order. From this result, the top $50 \%$ of the load buses are considered as optimal locations for placing the DGs.

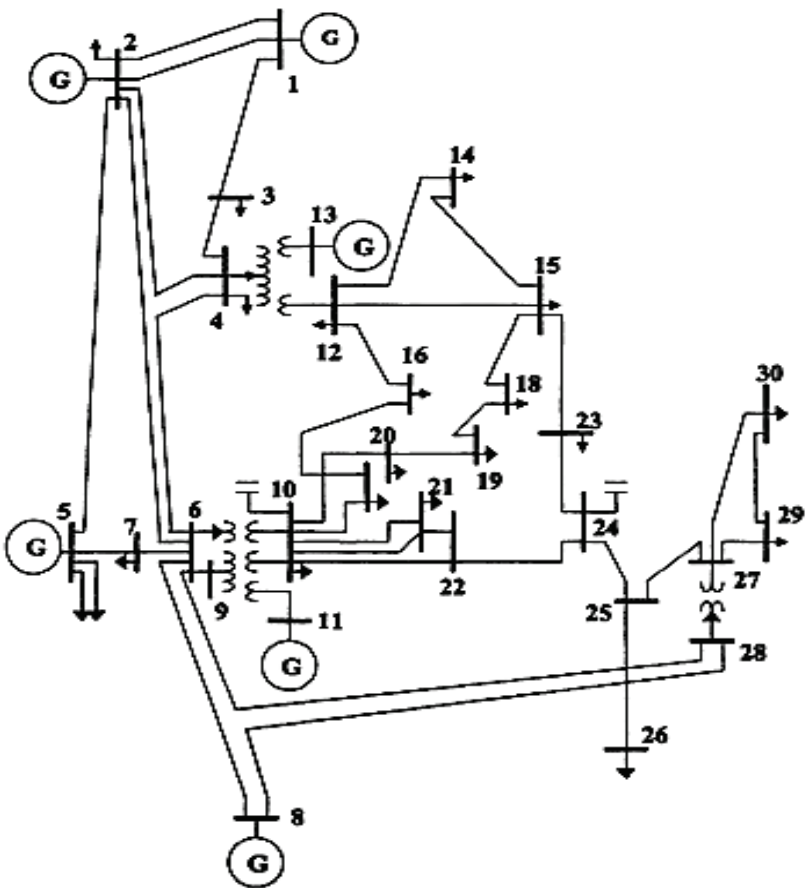

Figure 3 Single line diagram of IEEE 30 bus system

Table 2 Optimal location and size of IEEE 30 bus system

\begin{tabular}{|c|c|c|}
\hline No of DGs & Best Location & DG sizes in MW \\
\hline 1 & 28 & 4.906 \\
\hline 2 & 5 & 4.975 \\
\hline 3 & 6 & 4.980 \\
\hline 4 & 9 & 4.963 \\
\hline 5 & 11 & 4.969 \\
\hline 6 & 15 & 4.999 \\
\hline 7 & 10 & 4.997 \\
\hline 8 & 12 & 4.891 \\
\hline 9 & 4 & 4.881 \\
\hline 10 & 16 & 4.942 \\
\hline 11 & 18 & 4.976 \\
\hline 12 & 20 & 4.933 \\
\hline
\end{tabular}

The optimal locations and their corresponding sizes of DG units for IEEE 30 bus system are given in Tab. 2 . The buses $28,5,6,9,11,15,10,12,4,16,18,20$ are the 12 optimal locations for DG placement based on the THD values. After finding these optimal locations, the efforts are focused towards the finding of optimal capacity of DGs, to be connected in these preferred locations, with the help of PSO algorithm. The DG penetration level of $59.412 \%$ is obtained by considering the total DG capacity as 60 MWand it is presented in Tab. 3. The same procedure is also applied for IEEE 57 bus system.

Table 3 Optimal penetration level for IEEE 30 bus system

\begin{tabular}{|c|c|c|c|}
\hline Sl. No. & $\begin{array}{c}\text { Total number of } \\
\text { DGs }\end{array}$ & $\begin{array}{c}\text { Total DG } \\
\text { capacity }\end{array}$ & $\begin{array}{c}\text { Penetration } \\
\text { level in } \%\end{array}$ \\
\hline 1. & 12 & $60 \mathrm{MW}$ & $59.412 \%$ \\
\hline
\end{tabular}

The comparison of real power losses without and with DG for IEEE 30 bus system is given in Tab. 4. After the placement of DGs, the reduction in real power losses has occurred from $2.4438 \mathrm{MW}$ to $1.6772 \mathrm{MW}$. In this case, the values of percentage reduction in real power losses are observed as $31.3696 \%$.

Table 4 Comparison of losses for IEEE 30 bus system without and with \begin{tabular}{|c|c|c|c|}
\hline $\begin{array}{c}\text { Losses without } \\
\text { DG in MW }\end{array}$ & $\begin{array}{c}\text { Losses with } \\
\text { DGs in MW }\end{array}$ & $\begin{array}{c}\text { Reduced } \\
\text { Losses } \\
\text { in MW }\end{array}$ & $\begin{array}{c}\text { Reduced } \\
\text { Losses in \% }\end{array}$ \\
\hline 2.4438 & 1.6772 & 0.7666 & 31.3696 \\
\hline
\end{tabular}

The improvement in the voltage profile is noticed, after optimally placing the DGs and the comparison graph is shown in Fig. 4. An optimal penetration level of 59.412 $\%$ is obtained for IEEE 30 bus system using PSO algorithm and the convergence characteristic is shown in Fig. 5.

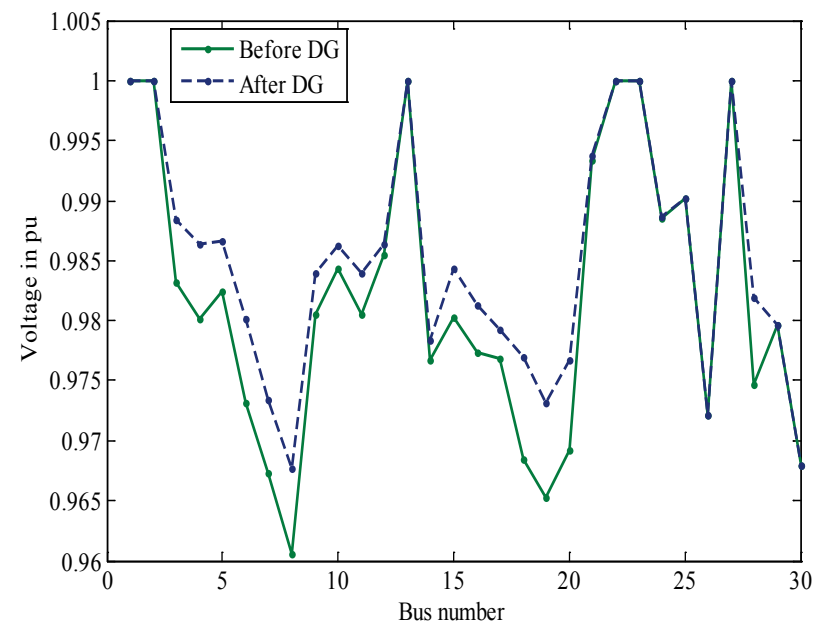

Figure 4 Improved voltage profile of IEEE 30 bus system

It is apparent from Fig. 4 that there is a notable improvement in voltages of all the buses of this test system, after the placement of DG units. 


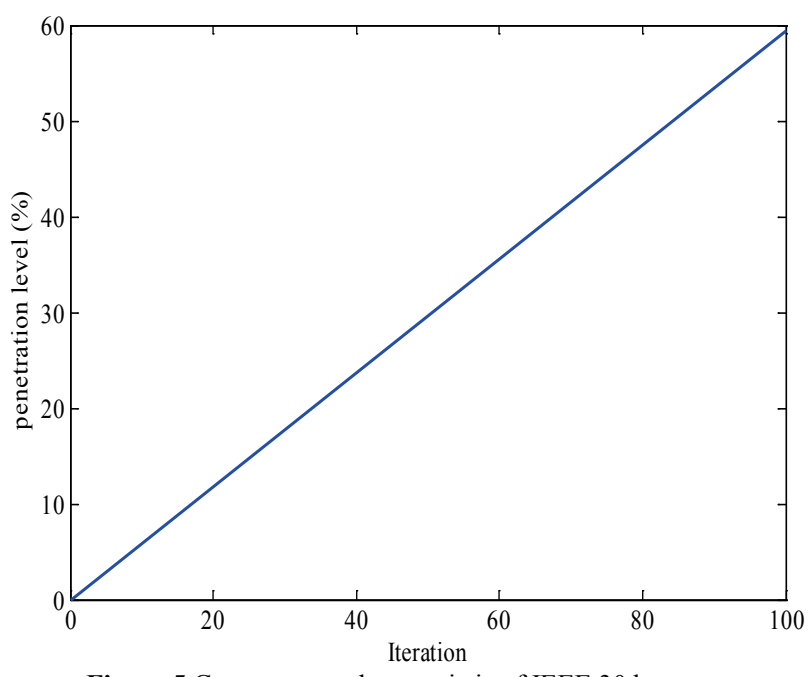

Figure 5 Convergence characteristic of IEEE 30 bus system

\subsection{Case II - IEEE 57 bus system}

In this case, the simulation tests are performed in IEEE 57 bus system. This power system network has 7 generators, 42 loads and 80 branches. The single line diagram of IEEE 57 bus system is shown in Fig. 6 .

The following assumptions are observed in this methodology for IEEE 57 bus system.

- The boundaries of bus voltages are set up as 0.95 and 1.06 p.u., respectively.

- The maximum number of DG units is considered as 25.

- The minimum and maximum values of DG are limited between $0.1 \div 3 \mathrm{MW}$, respectively.

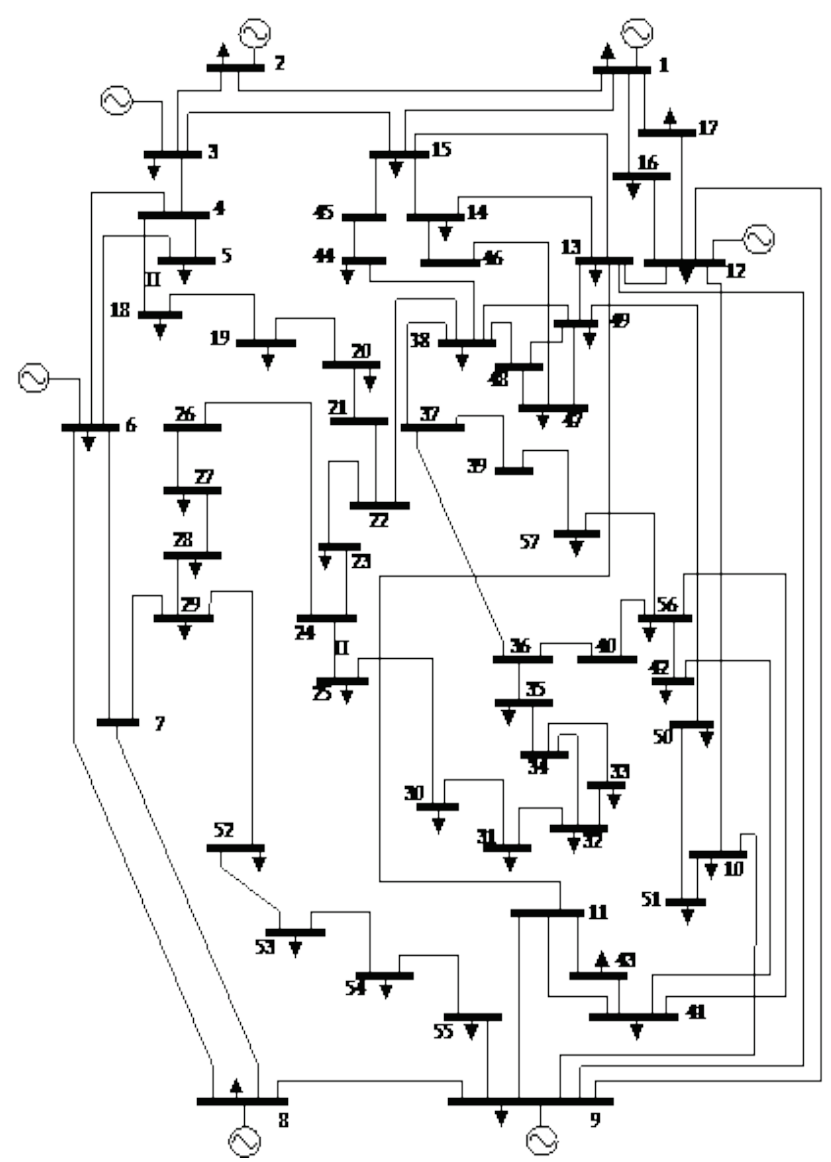

Figure 6 Single line diagram of IEEE 57 bus test system
Table 5 Optimal location and size of IEEE 57 bus system

\begin{tabular}{|c|c|c|}
\hline No. of DGs & Best Location & DG sizesin MW \\
\hline 1 & 11 & 2.7982 \\
\hline 2 & 4 & 2.9363 \\
\hline 3 & 24 & 2.9884 \\
\hline 4 & 26 & 2.9013 \\
\hline 5 & 7 & 2.8239 \\
\hline 6 & 39 & 2.8355 \\
\hline 7 & 37 & 2.9519 \\
\hline 8 & 34 & 2.9849 \\
\hline 9 & 13 & 2.7412 \\
\hline 10 & 40 & 2.8623 \\
\hline 11 & 36 & 2.9980 \\
\hline 12 & 27 & 2.9606 \\
\hline 13 & 38 & 2.9422 \\
\hline 14 & 45 & 2.8167 \\
\hline 15 & 16 & 2.9554 \\
\hline 16 & 56 & 2.9947 \\
\hline 17 & 46 & 2.9936 \\
\hline 18 & 41 & 2.7906 \\
\hline 19 & 32 & 2.8479 \\
\hline 20 & 14 & 2.8722 \\
\hline 21 & 25 & 2.9059 \\
\hline 22 & 49 & 2.9240 \\
\hline 23 & 48 & 2.9894 \\
\hline 24 & 22 & 2.9063 \\
\hline 25 & 31 & 2.7270 \\
\hline
\end{tabular}

Base case load flow is performed and the corresponding values of power flows, bus voltages and line losses of test system are observed. The procedure for finding an optimal placement and sizing of DG is same as that of IEEE 30 bus system. The optimal locations and their corresponding sizes of DGs for IEEE 57 bus system are tabulated in Tab. 5.

The DG penetration level of $72.449 \%$ is obtained by considering the total DG capacity as $75 \mathrm{MW}$ is tabulated in Tab. 6 .

Table 6 Optimal penetration level for IEEE 57 bus system

\begin{tabular}{|c|c|c|c|}
\hline Sl. No. & $\begin{array}{c}\text { Total number of } \\
\text { DGs }\end{array}$ & $\begin{array}{c}\text { Total DG } \\
\text { capacity }\end{array}$ & Penetration level \\
\hline 1. & 25 & $75 \mathrm{MW}$ & $72.449 \%$ \\
\hline
\end{tabular}

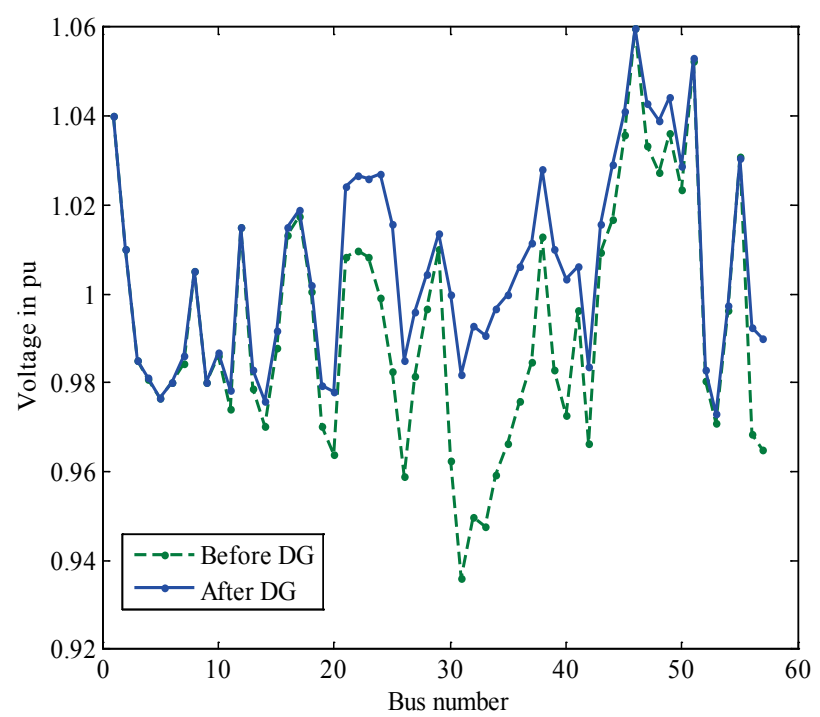

Figure 7 Improved voltage profile of IEEE 57 bus system

The comparison of real power losses for IEEE 57 bus system without and with DG is tabulated in Tab. 7. After 
placing the DGs, the real power loss is reduced from $27.8638 \mathrm{MW}$ to $20.1503 \mathrm{MW}$. The value of percentage reduction in real power losses is nearly $27.683 \%$ for IEEE 57 bus system. The improvement in voltage profile of this test system after optimally placing the DGs is observed and it is shown in Fig. 7. An optimal penetration level of $72.449 \%$ is obtained for 57 bus system, using PSO algorithm. The corresponding convergence characteristic is shown in Fig. 8. The optimal penetration level is directly identified from this convergence characteristic curve.

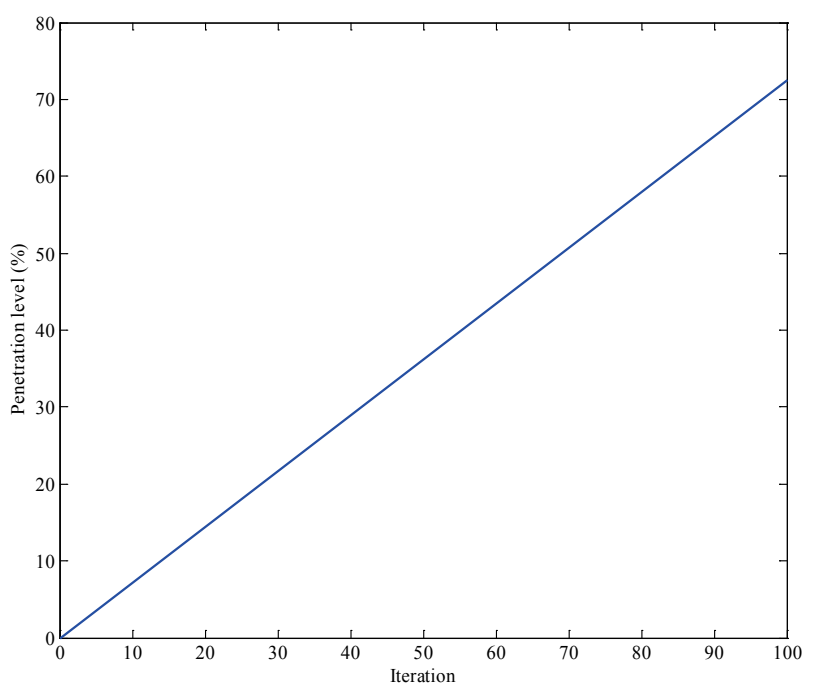

Figure 8 Convergence characteristic of IEEE 57 bus system

Table 7 Comparison of losses for IEEE 57 bus system without and with DG units

\begin{tabular}{|c|c|c|c|}
\hline $\begin{array}{c}\text { Losses without } \\
\text { DG in MW }\end{array}$ & $\begin{array}{c}\text { Losses with } \\
\text { DGs in MW }\end{array}$ & $\begin{array}{c}\text { Reduced } \\
\text { Losses in MW }\end{array}$ & $\begin{array}{c}\text { Reduced } \\
\text { Losses in \% }\end{array}$ \\
\hline 27.8638 & 20.1503 & 7.7134 & 27.683 \\
\hline
\end{tabular}

The results obtained in this proposed algorithm are compared with the results reported in existing literature [8] and [22]. The comparison of results in number of DG units, penetration level and real power losses is also tabulated in Tab. 8

It can be easily noted down from Tab. 8 that the number of DG units, percentage of penetration level and percentage of loss reduction by this proposed method are $12,59.412 \%$ and $31.37 \%$, respectively. These results prove their supremacy in yielding a better penetration and loss reduction levels than the results reported in contemporary literature [22] and [8].

Table 8 Comparison of results: Proposed algorithm Vs. Existing

\begin{tabular}{|c|c|c|c|c|c|}
\hline $\begin{array}{c}\text { Sl. } \\
\text { No. }\end{array}$ & Method & $\begin{array}{c}\text { Test } \\
\text { system } \\
\text { of } \\
\text { DGs }\end{array}$ & $\begin{array}{c}\text { No. } \\
\text { Penetration } \\
\text { level in \% }\end{array}$ & $\begin{array}{c}\% \\
\text { reduction } \\
\text { in real } \\
\text { power } \\
\text { losses }\end{array}$ \\
\hline 1 & $\begin{array}{c}\text { Proposed } \\
\text { method }\end{array}$ & 30 bus & 12 & 59.412 & 31.37 \\
\hline 2 & $\begin{array}{c}\text { PSO algorithm } \\
{[22]}\end{array}$ & 14 bus & 6 & 26.94 & $\begin{array}{c}\text { Not } \\
\text { reported }\end{array}$ \\
\hline 3 & $\begin{array}{c}\text { ABC algorithm } \\
{[8]}\end{array}$ & 33 bus & 1 & $\begin{array}{c}\text { Not } \\
\text { reported }\end{array}$ & 28.19 \\
\hline
\end{tabular}

\section{Statistical Investigation}

To validate the sturdiness of this proposed approach, in reaching the optimal or near optimal solution, 25 independent and continuous runs are performed with the same level of maximum iteration, i.e., 100 iterations with three different particle sizes i.e. 20, 40 and 60 . The results are compared with the statistical investigation and they are given in Tab. 9. It is clear from Tab.9 that the simulation using 60 particles is the most preferred one, because the value of standard deviation is comparatively less.

Table 9 Statistical analysis with 25 independent runs

\begin{tabular}{|c|l|c|c|c|}
\hline \multicolumn{2}{|c|}{ No. of particles } & 20 & 40 & 60 \\
\hline \multirow{3}{*}{$\begin{array}{c}\text { Total } \\
\text { fitness } \\
\text { value }\end{array}$} & Best & 58.6526 & 59.1509 & 59.4104 \\
\cline { 2 - 5 } & Worst & 55.3569 & 57.5761 & 58.385 \\
\cline { 2 - 5 } & Mean & 57.2612 & 58.4653 & 59.0143 \\
\cline { 2 - 5 } & Standard deviation & 0.72739 & 0.38986 & 0.26216 \\
\hline \multicolumn{2}{|c|}{ Calculation time } & $1 \mathrm{Min} 24$ & $1 \mathrm{Min} 37$ & $1 \mathrm{Min} 69$ \\
& $\mathrm{Sec}$ & $\mathrm{Sec}$ & $\mathrm{Sec}$ \\
\hline
\end{tabular}

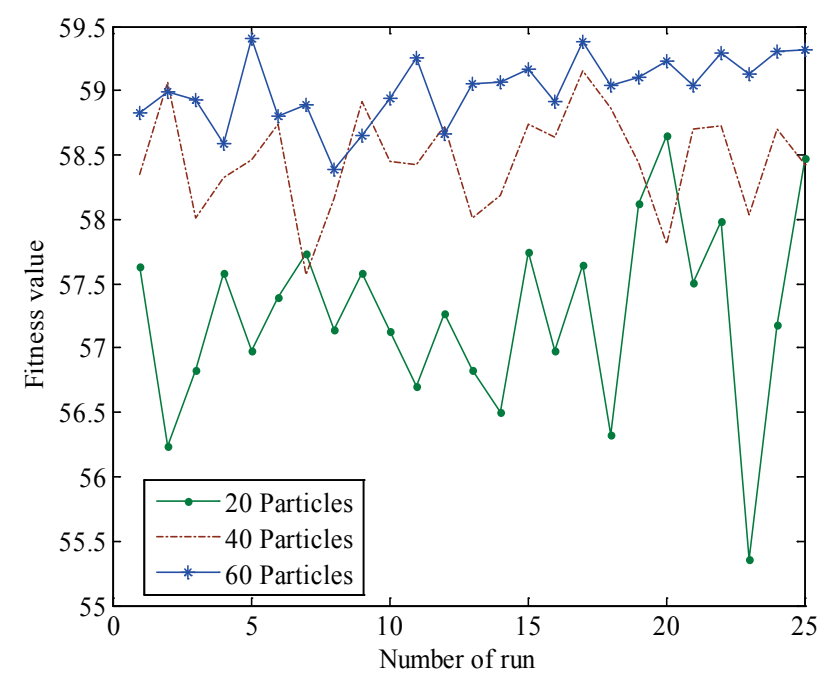

Figure. 9 Plot with different particle size

The comparative plot between fitness value and number of run with 20,40 and 60 particles is shown in Fig. 9. The maximum and minimum values of 25 independent runs with 20, 40 and 60 particles are easily noted down from Fig. 9. The fitness value with 60 particles is comparatively high among these three values.

\section{Conclusion}

A new method of finding the optimal placement and capacity of distributed generation using the Particle Swarm Optimization is implemented in IEEE 30 and IEEE 57 bus systems. The improper location and size of DG units can cause major disruptions in the operating parameters of power system network. The DG penetration level is normally limited by fault current levels, protection coordination of relays, stability and power quality issues.

The objective of this proposed optimization problem is to maximize the DG penetration level, subject to power balance constraints, bus voltage limits, total and individual harmonic distortion limits. The outcome of this approach has indicated that the maximum DG penetration level is limited by harmonic distortion level. Therefore, in this paper the bus corresponding to the minimum value of 
THD is identified as the optimal location of DGs. The optimal DG penetration level is achieved, by PSO based optimization algorithm, with an objective of improving the voltage profile and reducing the losses in the system.

In the existing literature the maximum DG penetration level is only obtained for IEEE 14 bus system using MATLAB, but in this work along with the maximum DG penetration, an improved voltage profile and minimum real power losses are also obtained for IEEE 30 and IEEE 57 bus systems using MATPOWER 4.1 version. The proposed optimization method can serve as a good planning tool for the utility operator to optimally allocate the DG units of different types in order to achieve better penetration level.

\section{Acknowledgements}

The authors are very thankful to the authorities of Anna University Regional Office, Madurai and Thiagarajar College of Engineering, Madurai for providing all the necessary facilities and a motivating support towards this research.

\section{References}

[1] Jenkins, N.; Allan, R.; Crossley, P.; Kirschen, D.; Strbac, G. Embedded Generation. // Institution of Engineering and Technology, 2008.

[2] Bollen, M. H.; Hassan, F. Integration of Distributed Generation in the Power System. // Wiley-IEEE Press, New York, 2011. https://doi.org/10.1002/9781118029039

[3] IEEE Standard for Interconnecting Distributed Resources with Electric Power Systems. // IEEE Std. vol. 15, 2009. Pp. 1547-2003.

[4] Smartconnect Use Case: D9-Utility Manages UtilityOwned Distributed Generation. http:/asset.sce.com/ microsite/Documents/ESC/D9 Use Case 081223.pdf.

[5] Algarni, A.; Bhattacharya, $\bar{K}$. Utility-owned DG units impacts on distribution system operation. // Proc. IEEE/PES Power Systems Conf. Expo., PSCE'09, 2009, pp. 1-6. https://doi.org/10.1109/PSCE.2009.4840190

[6] Schwarzenegger, A. Renewable distributed generation assessment. // Sacramento municipal utility district case study Utility Project Report, 2005.

[7] Jabr, R.; Pal, B. Ordinal optimisation approach for locating and sizing of distributed generation. // IET Gen., Transm., Distrib. 3, 8(2009), pp. 713-723. https://doi.org/10.1049/iet-gtd.2009.0019

[8] Abu-Mouti, F.; El-Hawary, M. Optimal distributed generation allocation and sizing in distribution systems via artificial bee colony algorithm. // IEEE Trans. Power Del. 26, 4(2011), pp. 2090-2101 https://doi.org/10.1109/TPWRD.2011.2158246

[9] Dugan, R.; McDermott, T.; Ball, G. Planning for distributed generation. // IEEE Ind. Appl. Mag. 7, 2, (2001), pp. 80-88.

[10] Luna, L.; Parra, E. Feasibility assessment of distributed generation interconnection. // Proc. IEEE Trondheim Power Tech., 2011, pp. 1-7. https://doi.org/10.1109/PTC.2011.6019404

[11] Carrasco, J.; Franquelo, L.; Bialasiewicz, J.; Galvan, E.; Guisado, R.; Prats, M.; Leon, J.; Moreno-Alfonso, N.; Power-electronic systems for the grid integration of renewable energy sources: A survey. // IEEE Trans. Ind. Electron. 53, 4(2006), pp. 1002-1016. https://doi.org/10.1109/TIE.2006.878356

[12] IEEE Recommended Practices and Requirements for Harmonic Control in Electrical Power Systems. // IEEE Std. 519-1992, 1993.
[13] Shayani, R.; de Oliveira, M. Photovoltaic generation penetration limits in radial distribution systems. // IEEE Trans. Power Syst. 26, 3(2011), pp. 1625-1631. https://doi.org/10.1109/TPWRS.2010.2077656

[14] Hung, D. Q.; Mithulananthan, N.; Bansal, R. C. Analytical expressions for DG allocation in primary distribution networks. // IEEE Trans. Energy Convers. 25, 3(2010), pp. 814-820. https://doi.org/10.1109/TEC.2010.2044414

[15] Herraiz, S.; Sainz, L.; Clua, J. Review of harmonic load flow formulations. // IEEE Trans. Power Del. 18, 3(2003), pp. 1079-1087. https://doi.org/10.1109/TPWRD.2003.813604

[16] Pamplona, F.; Souza, B. Harmonic passive filter planning in radial distribution systems using genetic algorithms. // Proc. IEEE/PES Transmission and Distribution Conf. Expo.: Latin America, 2004, pp. 126-131. https://doi.org/10.1109/TDC.2004.1432364

[17] Hong, Y. Y.; Huang, W. F. Interactive multi objective passive filter planning with fuzzy parameters in distribution systems using genetic algorithms. // IEEE Trans. Power Del. 18, 3(2003), pp. 1043-1050. https://doi.org/10.1109/TPWRD.2003.813630

[18] Masoum, M. A. S.; Jafarian, A.; Ladjevardi, M.; Fuchs, E. F.; Grady, W. M. Fuzzy approach for optimal placement and sizing of capacitor banks in the presence of harmonics. // IEEE Trans. Power Del. 19, 2(2004), pp. 822-829. https://doi.org/10.1109/TPWRD.2003.823187

[19] Chang, G. W.; Wang, H.-L.; Chuang, G. S.; Chu, S. Y. Passive harmonic filter planning in a power system with considering probabilistic constraints. // IEEE Trans. Power Del. 24, 1(2009), pp. 208-218. https://doi.org/10.1109/TPWRD.2008.2005371

[20] Singh, R. K.; Goswami, S. K. Optimum Siting and Sizing of Distributed Generations in Radial and Networked Systems Electric Power Components and Systems, 2009, pp. 127-145.

[21] Eberhart, R.C.; Shi, Y. Particle swarm optimization: Developments, applications and resources. // Proc. Congr. Evolutionary Computation. 1, (2001), pp. 81-86. https://doi.org/10.1109/CEC.2001.934374

[22] Ravikumarpandi, V.; Zeineldin, H. H.; Xiao, Weidong. Determining Optimal Location and Size of Distributed Generation Resources Considering Harmonic and Protection Coordination Limits. // IEEE Transactions on Power Systems. 28, 2(2013), pp. 1245-1254. https://doi.org/10.1109/TPWRS.2012.2209687

[23] Ray, D.; Zimmerman C.; Murillo-Sanchez, E. MATPOWER version 4.0. http://www.pserc.cornell.edu/ matpower/first submitted by MATLAB Central Team on 15 Apr 2006.

\section{Authors' addresses}

R. M. Sasiraja, M.E., Ph.D. Faculty

T. Abinaya, B.E., PG Scholar

Department of Electrical and Electronics Engineering

Anna University Regional Campus

Madurai - 625 019, Tamil Nadu, India

E-mail: rmsasiraja@gmail.com

E-mail: abinayatamizhan@gmail.com

K. Muthulakshmi, M.E., Ph.D., Associate Professor Kamaraj College of Engineering and Technology

Virudhunagar - 626 001, Tamil Nadu, India

E-mail: muthusashi@gmail.com

V. Suresh Kumar, M.E., Ph.D., Associate Professor

Thiagarajar College of Engineering

Madurai - 625 015, Tamil Nadu, India

E-mail: vskeee@tce.edu 